\title{
PENEGAKAN HUKUM TERHADAP KORPORASI DALAM TINDAK PIDANA LINGKUNGAN DI WILAYAH PROVINSI JAWA BARAT DIHUBUNGKAN DENGAN UPAYA PEMULIHAN LINGKUNGAN HIDUP
}

\author{
Siti Suryati \\ Pengadilan Tinggi Banjarmasin \\ Zikl.ziti@yahoo.com \\ DOI: https://doi.org/10.29313/sh.v16i2.5355
}

\begin{abstract}
ABSTRAK
Eksploitasi lingkungan oleh korporasi di Provinsi Jawa Barat menimbulkan berbagai kerusakan ekosistem, tetapi penegakan hukum kesulitan menuntut pertanggungjawaban hukum korporasi sebagai pelaku tindak pidana lingkungan. Tujuan penelitian: (1) Untuk mengetahui implementasi penegakan hukum terhadap korporasi di wilayah Provinsi Jawa Barat. (2) Untuk menemukan upaya optimalisasi sanksi pidana terhadap korporasi dalam tindak pidana lingkungan di wilayah Provinsi Jawa Barat sebagai upaya pemulihan lingkungan. Penelitian ini menggunakan pendekatan yuridis normatif. Spesifikasi penelitian adalah deskriptif analisis. Jenis data yang digunakan data sekunder. Teknik pengumpulan data studi kepustakaan dan teknik analisis menggunakan pendekatan kualitatif. Implementasi penegakan hukum pidana terhadap tindak pidana korporasi di wilayah Provinsi Jawa Barat secara faktual hanya sedikit korporasi yang dikenakan sanksi pidana karena kesulitan untuk membuktikan unsur delik yang dalam penyajian data dan faktanya seringkali bersifat ilmiah (scientific proof) dan terbentur beberapa persoalan mendasar yang menjadi kendala yaitu (a) ketidakkelasan kriteria rumusan delik (b) keterbatasan sumber daya manusia (c) sarana dan prasarana (d) masalah anggaran. Upaya penegakan hukum pidana terhadap tindak pidana korporasi lingkungan di Provinsi Jawa Barat berupa (a) menjatuhkan pidana penjara kepada pengurus korporasi (b) menerapkan sanksi pidana denda yang dikelola oleh KLHK dan digunakan untuk kepentingan pemulihan lingkungan (c) menjatuhkan sanksi pidana tambahan yaitu perbaikan akibat tindak pidana.
\end{abstract}

Kata Kunci: Penegakan Hukum, Korporasi, Pemulihan Lingkungan Hidup

\section{ABSTRACT}

Environmental exploitation by corporations in the province of West Java has caused various ecosystem damage, but law enforcement has difficulty in demanding corporate legal responsibility as perpetrators of environmental crimes. Research objectives: (1) To determine the implementation of law enforcement against corporations in the area of West Java Province. (2) To find efforts to optimize criminal sanctions against corporations in environmental crime in the area of West Java Province as an effort to restore the environment. This research uses a normative 
juridical approach. The research specification is descriptive analysis. The type of data used is secondary data. Literature study data collection techniques and analysis techniques use a qualitative approach. The implementation of criminal law enforcement against corporate criminal acts in the area of West Java Province is factually only a few corporations are subject to criminal sanctions because of the difficulty to prove the offense element in the presentation of data and the facts are often scientific (scientific proof) and hampered by a number of fundamental issues which become obstacles namely (a) unclear criteria for offense formulation (b) limited human resources (c) facilities and infrastructure (d) budget problems. Efforts to enforce criminal law against environmental corporate criminal acts in West Java Province in the form of (a) imprisonment of corporations (b) applying criminal sanctions for fines managed by KLHK and used in the interests of environmental restoration (c) imposing additional criminal sanctions namely repairs due criminal act..

Keywords: Law Enforcement, Corporation, Environment Recovery.

\section{A. PENDAHULUAN}

\section{Latar Belakang Masalah}

Tindak pidana pencemaran dan perusakan lingkungan di wilayah Provinsi Jawa Barat pada umumnya terjadi karena proses eksploitasi lingkungan hidup yang tidak sesuai dengan ketentuan perundang-undangan di bidang lingkungan hidup. Eksploitasi lingkungan hidup di Provinsi Jawa Barat banyak dilakukan oleh perusahaan-perusahaan besar untuk memperoleh keuntungan sebesar-besarnya. Akan tetapi tanpa diimbangi dengan usaha pelestarian lingkungan hidup.

Berdasarkan uraian di atas, maka penjatuhan sanksi pidana bertujuan untuk memberikan efek jera dan sebagai upaya pencegahan (deterrence) bagi pihak-pihak yang akan melakukan tindak pidana lingkungan hidup. Namun demikian, penjatuhan sanksi pidana kepada pelaku pencemaran/perusakan lingkungan hidup khususnya di Provinsi Jawa Barat efektivitasnya masih dipersoalkan, dikarenakan selama ini telah ada beberapa perusahaan yang telah dijatuhi sanksi pidana berupa penjara dan/atau denda, akan tetapi intensitas kegiatan pencemaran/perusakan lingkungan hidup di Provinsi Jawa Barat masih cukup tinggi. Seperti dalam tabel di bawah ini: ${ }^{1}$

\footnotetext{
${ }^{1}$ Rekapitulasi Data Dinas Lingkungan Hidup Jawa Barat, November 2017.
} 


\begin{tabular}{|c|c|c|c|c|c|c|c|}
\hline No & Tahun & Individu & Korporasi & $\begin{array}{c}\text { Jumlah } \\
\text { Perkara }\end{array}$ & \multicolumn{2}{|c|}{ Penanganan } \\
\hline$(1)$ & $(2)$ & $(3)$ & $(4)$ & $(5)$ & \multicolumn{2}{|c|}{ Adm Mediasi Pidana } \\
\hline 1 & 2014 & 156 & 16 & 172 & 69 & 1 & 12 \\
\hline 2 & 2015 & 149 & 32 & 181 & 114 & 1 & 11 \\
\hline 3 & 2016 & 133 & 65 & 198 & 195 & - & 3 \\
\hline & Total & $\mathbf{4 3 8}$ & $\mathbf{1 1 3}$ & $\mathbf{5 5 1}$ & $\mathbf{3 7 8}$ & $\mathbf{2}$ & $\mathbf{2 6}$ \\
\hline
\end{tabular}

Sumber: Dinas Lingkungan Hidup Jabar, Tahun 2016

Data tahun 2014-2016 menunjukkan 378 kasus lebih diarahkan untuk diselesaikan melalui instrumen hukum administrasi. Penegak hukum memandang penyelesaian dengan menggunakan sanksi administrasi lebih efektif dengan biaya murah. Meski demikian dari 378 perkara yang selesai secara administrasi hanya 40\% yang melaksanakan sanksi administrasi, sisanya tidak melaksanakan atau melaksanakan tetapi tidak secara tuntas. Keadaan ini membuat para pelaku perorangan maupun korporasi tidak jera untuk mengulangi atau melanjutkan perbuatan yang merusak lingkungan. Ada 2 (dua) perkara yang di mediasi karena pelaku bersedia menghentikan dan memulihkan lingkungan yang rusak. Sisanya 26 diselesaikan secara pidana karena gagal ditangani dengan hukum administrasi maka harus diadili secara pidana. Total dari 551 kasus, yang ditangani secara administrasi, mediasi dan pidana hanya 406 kasus, sisanya sebanyak 145 kasus tidak ditindaklanjuti karena tidak cukup bukti sehingga tidak dilanjutkan ke tingkat penyidikan.

Berdasarkan hasil inventarisasi persoalan penegakan hukum lingkungan yang dilakukan korporasi di wilayah Jawa Barat meliputi:

Pertama, Persoalan tumpang tindih proses penyidikan, selama ini penegakan hukum lingkungan ditangani oleh tiga lembaga penegak hukum yaitu Kepolisian, Kejaksaan dan Penyidik Pegawai Negeri Sipil dari Dinas Lingkungan Hidup. Ketiga institusi penegak hukum ini berjalan sendiri-sendiri sehingga dalam praktek sering ditemukan ada 1 (satu perusahaan ditangani lebih dari institusi penegak hukum. Masalah ini mencerminkan lemahnya koordinasi antar lembaga penegak hukum, arogansi kekuasaan penegakan hukum yang menimbulkan ketidakpastian hukum bagi pelaku dan korban. Pada tahun 2014 Gubernur membentuk Satuan Tugas Penegakan Hukum Lingkungan Terpadu dengan mengeluarkan Keputusan No 188.44/Kep 1836- 
Hukham/2014 Tanggal 31 Desember 2014. Satgas ini terdiri dari sub yaitu (1) Satuan Tugas Data dan Informasi (2) Satgas Bidang Penegakan Hukum (3) Satgas Tindak Pidana Korupsi dan Pencucian Uang yang berkaitan dengan lingkungan. Meski telah dibentuk Satgas khusus tindak pidana lingkungan yang dilakukan korporasi sedikit yang bisa ditangani oleh Satgas karena kejahatan ini merupakan jenis kejahatan kerah putih (white collar crime) yang melibatkan pengusaha bermodal besar yang berusaha meloloskan diri dari jerat hukum dengan melakukan upaya seperti, menghilangkan barang bukti, mempengaruhi integritas penegak hukum dan lain-lain.

Kedua, Perbedaan pemahaman aparat penegak hukum dalam penerapan hukum pidana lingkungan. Aparat penegak hukum masih berbeda persepsi tentang siapa yang harus bertanggungjawab. Normatifnya harus ada pelaku fisik (physical perpetrator). Apakah direksi yang harus dimintai pertanggungjawaban pidana atau juga pejabatpejabat lain yang terkait dalam pengambilan kebijakan dalam korporasi yang menimbulkan tindak pidana lingkungan.

Ketiga, masalah pembuktian tindak pidana lingkungan memiliki tingkat kerumitan dibanding dengan tindak pidana lain. Sebagai contoh masalah "baku mutu lingkungan" penyidik harus meminta pendapat ahli yang bersifat ilmiah. Penyidik mengalami kesulitan ketika para ahli berbeda pendapat. Apalagi ahli yang dihadirkan penyidik dengan ahli yang dihadirkan perusahaan saling berbeda pandangan saat pembuktian. Akibatnya penyidik atau penuntut umum tidak melakukan pembuktian secara keseluruhan yang membuat pelaku bebas atau hanya dipidana dengan pidana percobaan.

Keempat, persoalan bobot sanksi yang dijatuhkan kepada pelaku, keinginan memidanakan korporasi yang terlibat kasus pidana lingkungan tidak mudah direalisasikan. Secara nasional bila mengacu pada data Simposium Corporation Crime Bidang Lingkungan Hidup yang diselenggarakan Masyarakat Hukum Pidana dan Kriminologi (Mahupiki). Jumlah 70 kasus pidana lingkungan periode 2000-2016, 43\% terdakwa divonis bebas, $40 \%$ hanya pidana percobaan, $2 \%$ onslag van gewisjde (lepas dari tuntutan hukum) dan 2 persen tuntutan ditolak. Hanya $13 \%$ pelaku pidana. Penjara 
dan denda. ${ }^{2}$ Untuk wilayah Jawa Barat jumlah sanksi pidana yang dijatuhkan pada korporasi pada tahun 2014 dari 172 kasus hanya 12 yang dijatuhi sanksi pidana, 2015 dari 181 kasus hanya 11 kasus dan 2016 dari 198 kasus hanya 3 dikenakan sanksi pidana. Sisanya ditangani secara administrasi dan mediasi penal. ${ }^{3}$

Persoalan yang urgen untuk ditemukan solusinya adalah bagaimana sesungguhnya implementasi penegakan hukum lingkungan terhadap korporasi di wilayah Provinsi Jawa Barat dan bagaimana seyogyanya optimalisasi penegakan hukum pidana lingkungan yang ideal untuk diterapkan terhadap korporasi yang berorientasi pada upaya pemulihan lingkungan hidup. Kedua masalah ini penting untuk ditemukan jawabannya karena menyangkut perlindungan sumber daya alam yang menjadi penopang hidup bagi manusia hari ini dan di masa yang akan datang.

Lahirnya Undang-undang No 32 Tahun 2009 tentang Perlindungan dan Pengelolaan Lingkungan Hidup (UUPPLH) menunjukkan kuatnya kehendak negara untuk mengutamakan prinsip-prinsip pembangunan berkelanjutan. Aspek pidana dalam Undang-undang ini menegaskan bahwa penerapan berbagai ketentuan pidana tidak lagi didasarkan pada prinsip ultimum remedium penerapan ketentuan pidana sebagai upaya terakhir (/the last resort) akan tetapi menggunakan prinsip primum remedium. Pengecualian prinsip primum remedium hanyalah pada Pasal 100 Undang-undang No 32 Tahun 2009 yaitu ketentuan pidana mengenai pelanggaran baku mutu air limbah, baku mutu emisi dan baku mutu gangguan. Tindak pidana pelanggaran baku mutu ini hanya dapat diberlakukan apabila penegakan hukum administrasi telah dijatuhkan namun tidak dilaksanakan. Ketentuan pidana Pasal 100 ini juga dapat diterapkan pada usaha/kegiatan yang melakukannya lebih dari satu kali (repeated violator). ${ }^{4}$ Kejahatan

\footnotetext{
${ }^{2}$ Saifuddin, Tindak Pidana Lingkungan Korporasi, Makalah disampaikan pada Simposium Hukum Pidana, Universitas Lambung Mangkurat, Banjarmasin, 2015.hlm 14.

${ }^{3}$ BPLHD Tahun 2016

${ }^{4}$ Mas Achmad Santosa. Kata Pengantar dalam Sembiring. Raynaldo., (et.al). Anotasi Undang Undang Nomor 32 Tahun 2009 Tentang Perlindungan Dan Pengelolaan Lingkungan Hidup, Edisi Pertama, (Jakarta: Indonesian Center for Environmental Law (ICEL), 2014), hlm. xiii.
} 
korporasi sebagai extra ordinary crime berdampak tidak hanya bagi manusia tetapi juga lingkungan itu sendiri dan dalam waktu yang sangat lama. ${ }^{5}$

Undang-undang No 32 Tahun 2009 memberikan penjelasan tentang kriteria pengenaan hukuman terhadap pengurus korporasi. Perkembangan ini merupakan suatu perubahan paradigma dalam hukum pidana yang pada awalnya menganut prinsip bahwa "badan hukum tidak dapat melakukan tindak pidana oleh karenanya tidak dapat dihukum" (adagium hukum: societas delinquere non potest). ${ }^{6}$ Namun demikian sejalan dengan perkembangan kegiatan ekonomi di belahan dunia, gejala kriminalitas merupakan suatu kelanjutan dari kegiatan dan pertumbuhan ekonomi di mana korporasi banyak berperan dalam mendukung atau memperlancar kejahatan tersebut. ${ }^{7}$

\section{Identifikasi Masalah}

Artikel ini akan membahas Bagaimana kekuatan hukum perjanjian lisensi hak cipta atas lagu antara pencipta lagu dengan produser rekaman (label) dalam upaya perlindungan hak ekonomi bagi para pihak, dan bagaimana bentuk perjanjian lisensi hak cipta atas lagu antara pencipta lagu dengan produser rekaman (label) yang memberikan kepastian hukum perlindungan hak ekonomi para pihak?

\section{Metode Penelitian}

Metode penelitian dalam penulisan ini menggunakan pendekatan yuridis normatif karena penulis mengkaji peraturan perundang-undangan yang mengatur perlindungan hak cipta, jabatan notaris dengan menggunakan data sekunder melalui teknik studi kepustakaan dan dianalisis secara kualitatif.

${ }^{5}$ I.S. Susanto, Tinjauan Kriminologis tentang Kejahatan Ekonomi, Makalah pada Penataran Hukum Pidana dan Kriminologi, UNDIP, Semarang 23-30 November 1998, hlm. 5.

${ }^{6}$ Hartiwiningih, Hukum Lingkungan dalam Perspektif Kebijakan Hukum Pidana, UNS Surakarta, 2008, hlm 24.

${ }^{7}$ Mas Achmad Santosa. Op.cit, hlm. ix. 


\section{B. PEMBAHASAN}

\section{a. Implementasi Penegakan Hukum Terhadap Korporasi dalam Tindak Pidana Lingkungan Hidup Berdasarkan Undang-Undang No. 32 Tahun 2009 Tentang Perlindungan dan Pengelolaan Lingkungan Hidup di Wilayah Provinsi Jawa Barat}

Penanganan kasus pencemaran dan perusakan lingkungan hidup di Jawa Barat menggunakan sistem one roof enforcement system yang melibatkan beberapa institusi penegak hukum baik PPNS/DLH Jabar, Polda Jabar dan Kejati Jabar didukung dengan institusi Pemprov Jabar untuk saling bersinergi menuntaskan kasus lingkungan hidup.

Penegakan hukum lingkungan secara terpadu berdasarkan Peraturan Bersama antara Gubernur, Polda dan Kejati Jabar dan Pembentukan Satgas Penegakan Hukum Lingkungan Terpadu yang dibentuk tahun 2014 untuk menangani tindak pidana lingkungan di Jabar akan sulit mencapai hasil yang maksimal apabila tidak diimbangi dengan kemampuan sumber daya yang kompeten melakukan tindakan pro justitia terhadap korporasi di bidang lingkungan hidup.

Sejak dibentuknya Satgas penegakan hukum lingkungan terpadu banyak kasus tindak pidana lingkungan yang melibatkan korporasi sebagai pelaku tetapi diakui oleh penegak hukum (Kepolisian, Kejaksaan dan PPNS) banyak kasus yang tidak sampai ke pengadilan. Berbagai masalah pro justitia menjadi kendala yang menghambat jalannya pemeriksaan korporasi yang tertangkap. Dengan kata lain, implementasi penegakan hukum dalam menanggulangi tindak pidana lingkungan di Jawa Barat selama ini mengalami berbagai persoalan yang menjadi kendala penyelesaian kasus lingkungan. Faktor-faktor tersebut antara lain:

1. Faktor Undang-undang

Sebagaimana dijelaskan sebelumnya Undang-Undang No 32 Tahun 2009 Tentang Perlindungan dan Pengelolaan Lingkungan Hidup memiliki beberapa kelemahan dalam rumusannya. Ada berbagai perbuatan yang dikualifikasikan sebagai tindak pidana tetapi sulit untuk mengukur atau menentukan bahwa telah 
terjadi tindak pidana lingkungan. Sebagai salah satu contoh perbuatan yang mengakibatkan dilampauinya baku mutu air, udara, dan baku kerusakan lingkungan diancam dengan pidana. Namun tolak ukur atau kriteria untuk menentukan telah dilampauinya baku mutu kerusakan lingkungan dimaksud tidak diatur secara lengkap dalam peraturan berikutnya atau peraturan pelaksananya. Persoalan ini berdampak pada proses implementasi penegakan hukum, karena dari segi formulasi mengancam perbuatan tersebut dengan pidana, maka penegak hukum memproses pelanggar dengan aturan hukum pidana, ternyata setelah kasus berjalan penegakan hukumnya mengalami kemandegan (stagnasi), karena penyidik kesulitan untuk membuktikan unsur delik yang dirumuskan dalam Undang-undang.

Ketidakjelasan dalam kebijakan legislatif secara otomatis akan berdampak pada penegakan hukum di lapangan. Tidak sedikit penyidik dari Polda Jabar maupun PPNS merasa kesulitan untuk menyelesaikan kasus pencemaran udara, air, air laut karena ketiadaan aturan yang menentukan kriteria baku mengenai pencemaran udara, ambien air dan air laut.

Apabila dari segi norma hukumnya saja sudah menimbulkan perdebatan, maka akan menjadi persoalan yang berdampak pada tidak terselesaikannya penegakan hukum pidana lingkungan. Selama ini di Jawa Barat kondisi demikian kerap kali terjadi, sehingga penyidik benar-benar perlu mempertimbangkan arah penegakan hukum, apakah akan di bawa ke ranah pidana atau administrasi karena aturan yang bersifat dualistis.

\section{Sumber Daya Manusia}

Provinsi Jawa Barat menurut ensiklopedia memiliki luas wilayah 35.222, 18 KM2. Jumlah penduduknya 43.053.732 jiwa mencakup mereka yang tinggal di perkotaan sebanyak 28.282.915 jiwa (65\%) dan di daerah pedesaan sebanyak 14.770.817 jiwa (34, 31\%). Jawa Barat selama tiga dekade mengalami perkembangan ekonomi yang pesat. Saat ini peningkatan ekonomi modern ditandai dengan peningkatan pada sektor manufaktur dan jasa. Disamping perkembangan sosial dan infrastruktur, sektor manufaktur terhitung terbesar dalam memberikan 
kontribusinya melalui investasi, hampir tiga perempat dari industri-industri manufaktur non minyak berpusat di sekitar Jawa Barat.

Penindakan terhadap berbagai bentuk pencemaran dan perusakan lingkungan hidup ini menjadi tanggung jawab Gubernur, Bupati/Walikota di wilayah Jawa Barat. Namun Gubernur mendelegasikan kewenangan tersebut kepada instansi yang bertanggung jawab di bidang perlindungan dan pengelolaan lingkungan dalam hal ini adalah DLH Jawa Barat. DLH sebagai institusi yang berwenang di bidang penegak hukum lingkungan telah menerapkan one roof enforcement system. Sistem ini menitikberatkan adanya koordinasi Kepolisian, Kejaksaan dan PPNS pada tahap penyidikan. One roof enforcement system berbeda dengan sistem peradilan pidana karena dalam one roof ruang lingkup kerja penegak hukum hanya sampai tahap penyidikan dan penuntutan, sedangkan dalam sistem peradilan pidana lingkup kerja penegak hukum dimulai dari penyidikan sampai pelaksanaan putusan. Namun pelaksanaan one roof enforcement system dalam rangka (penindakan) dan pengawasan DLH secara kelembagaan memiliki keterbatasan/kelemahan di bidang sumber daya manusia, keterbatasan dimaksud antara lain:

1. Bidang Penegakan Hukum Lingkungan DLH Jawa Barat saat ini hanya mempunyai 20 orang staf;

2. Terdapat 5 orang PPLH (Pejabat Pengawas Lingkungan Hidup) sebagai Pejabat Fungsional di DLH Jabar untuk melakukan pengawasan di seluruh Jabar, sementara 5 orang tersebut bisa digunakan oleh semua bidang lain sesuai dengan kebutuhan tupoksi bidangnya masing-masing;

3. DLH Jabar hanya memiliki 2 orang PPNS-LH, itupun bukan pejabat fungsional, akan tetapi struktural yang mana pekerjaan secara struktural lebih melekat dibandingkan dengan pekerjaan penyidikannya sendiri;

4. Tidak mempunyai SDM yang mempunyai sertifikasi untuk pengambilan sampling sedangkan untuk pengambilan sampling yang 
diakui secara hukum yang melakukan PPLH/PPNS/Petugas sampling harus terakreditasi.

Keterbatasan SDM dalam menegakkan hukum pidana lingkungan di Jawa Barat tidak akan maksimal bila dibandingkan dengan demografi dan wilayahnya yang begitu luas serta banyaknya korporasi yang tersebar di Jabar. Minimnya SDM baik secara kualitas maupun kuantitas dalam institusi DLH maupun Kepolisian dan Kejaksaan akan cukup berpengaruh pada implementasi penegakan hukum pidana. Posisi penegak hukum baik dari segi jumlah personil maupun kemampuan dan kapasitasnya dalam menyelesaikan kasus korporasi lingkungan merupakan salah satu kunci keberhasilan implementasi penegak hukum terhadap tindak pidana lingkungan yang selama ini dilakukan oleh perusahaan.

3. Sarana dan Prasarana

Penegakan hukum pidana lingkungan merupakan suatu proses yang ditempuh dengan melalui berbagai tahapan-tahapan yang membutuhkan waktu yang lama dan membutuhkan sarana dan prasarana yang dapat menunjang kegiatan penindakan tersebut. Selama ini penegakan hukum pidana lingkungan memiliki kendala yang hampir sama dengan beberapa tindak pidana khusus yaitu persoalan sarana dan prasarana.

Masalah sarana seringkali menjadi penghambat kelancaran dalam proses percepatan penyelesaian pidana lingkungan. Namun sampai sekarang DLH Jabar belum memiliki sarana yang memadai untuk menunjang proses penyidikan maupun penuntutan. Beberapa masalah yang dihadapi berkaitan dengan sarana dan prasarana antara lain:

a. Tidak mempunyai laboratorium lingkungan tersendiri. Dalam kasus pencemaran misalnya, DLH harus bekerjasama dengan pihak swasta untuk menentukan cairan limbah yang mengakibatkan pencemaran air.

b. Kendaraan untuk di lapangan sangat terbatas, kendaraan sebagai sarana yang cukup dibutuhkan oleh penyidik untuk meninjau lokasi terjadinya dugaan tindak pidana lingkungan oleh korporasi. Tidak 
jarang dalam praktek penyidik harus meninjau langsung lokasi kerusakan atau pencemaran yang memiliki medan cukup berat dan sulit dilalui oleh kendaraan biasa. Butuh kendaraan khusus untuk sampai lokasi lebih cepat dan sarana tersebut belum terfasilitasi sampai sekarang.

c. Penyidik Pegawai Negeri Sipil (PPNS) memiliki kewenangan untuk melakukan penggeledahan terhadap badan, pakaian, ruangan, dan/atau tempat lain yang diduga merupakan tempat dilakukannya tindak pidana, juga kewenangan untuk menangkap dan menahan pelaku tindak pidana lingkungan sebagaimana dimaksud dalam Pasal 94 ayat (2). Namun selain karena jumlahnya yang terbatas juga PPNS tidak dilakukan pembinaan dan pelatihan militer terlebih dahulu dan tidak dilengkapi persenjataan yang memadai seperti penyidik Polri. Meskipun dalam ayat (3) PPNS diberikan kewenangan untuk melakukan koordinasi dengan penyidik Polri. Akan tetapi dalam praktek penyidik PPNS memerlukan kecepatan dalam pengungkapan tindak pidana lingkungan, sehingga apabila harus berkoordinasi lebih dulu dengan penyidik Polri, akan menimbulkan perlambatan dalam pengungkapan kasus.

Keberadaan sarana memiliki posisi penting yang berkaitan dengan percepatan penyidikan yang dilakukan oleh PPNS, Kepolisian dan Kejaksaan. Tanpa didukung dengan sarana dan prasarana yang memadai, maka dapat dipastikan penegakan hukum pidana lingkungan terhadap korporasi di Jawa Barat tidak akan memperoleh hasil maksimal terus mengalami hambatan. Contohnya seperti keberadaan Lab dan fasilitas kendaraan, memiliki pengaruh cukup besar agar dugaan adanya pencemaran atau perusakan lingkungan oleh korporasi dapat diketahui secara cepat dan pasti.

4. Permasalahan Anggaran

Anggaran selalu menjadi masalah yang kerap muncul dalam semua lini dan institusi penegakan hukum. Setiap tahun APBD Jawa Barat digelontorkan untuk 
membiayai birokrasi penegakan hukum lingkungan secara terpadu. Namun hasil yang dicapai tak kunjung memberikan kepuasan, terutama perbaikan terhadap fungsi lingkungan yang telah rusak.

Keterbatasan anggaran penegakan hukum lingkungan menyebabkan penanganan hukum menjadi tidak maksimal. Apalagi dengan terbentuknya one roof enforcement system/penegakan hukum lingkungan terpadu, bekerja sama antara Gubernur, Polda dan Kejati menyebabkan semua penganggaran penegakan hukum lingkungan dibebankan ke APBD, dalam hal ini pemerintah Provinsi Jawa Barat. Anggaran yang sangat minim dibandingkan dengan peruntukannya yang menjadi sangat luas karena melibatkan banyak sektor.

Selama ini karena keterbatasan anggaran, kendala inti dalam penegakan hukum lingkungan tidak diperhatikan. Anggaran yang ada habis untuk membiayai birokrasi penegakan hukum. Sementara masalah-masalah pokok seperti kecukupan SDM, sarana dan prasarana menjadi masalah penting yang diabaikan. Itu sebabnya persoalan ini selalu muncul setiap tahun ketika berbicara mengenai kendala penegakan hukum pidana lingkungan di Jawa Barat. Masalah ini menjadi persoalan kelembagaan yang harusnya dapat diselesaikan secara tuntas dan tidak berlarut- larut menghambat penegakan tindak pidana lingkungan di Jawa Barat.

Masalah-masalah yang menjadi hambatan sebagaimana diuraikan di atas sejalan sesuai dengan teori efektivitas penjatuhan sanksi yang dikemukakan oleh Soerjono Soekanto bahwa penegakan hukum akan dipengaruhi lima faktor yang saling bergelindan satu sama lain, yang satu tidak terpenuhi akan mempengaruhi unsur lainnya. Faktor-faktor yang dimaksud adalah (1) undang-undang; (2) penegak hukum; (3) sarana dan prasarana; (4) masyarakat; (5) kebudayaan.

Penegakan hukum tindak pidana pencemaran dan perusakan lingkungan mengalami kesulitan ketika berusaha membuktikan unsur-unsur delik, penyidik kasus lingkungan terutama ketika berhadapan dengan korporasi tidak selamanya mempunyai kapasitas untuk mengungkap hal-hal teknis. Sebagai contoh pembuktian adanya perbuatan yang melampaui baku mutu lingkungan. Pembuktian kasus ini bersifat ilmiah sehingga penyidik harus mendatangkan ahli. Persoalannya ketika 
para ahli berbeda pendapat dengan argumen yang sama-sama dapat diterima secara ilmiah dalam praktik membingungkan penyidik.

Rumitnya masalah pembuktian dalam tindak pidana lingkungan oleh korporasi membuat keinginan memidanakan korporasi tidak mudah direalisasikan. Sebagaimana diuraikan di atas, bahwa ada beberapa persoalan elementer yang menghambat implementasi penegakan hukum lingkungan seperti sarana laboratorium, penyidik yang tergabung dalam Satgas penegakan hukum lingkungan terpadu kesulitan untuk menguji adanya pencemaran air di media sungai karena ketiadaan laboratorium dan keterbatasan pengetahuan penyidik terkait masalah lingkungan. Meskipun adanya kesadaran tentang pentingnya menjaga lingkungan hidup di kalangan penegak hukum, faktanya tidak mudah menjerat pelaku. Berdasarkan data yang disajikan oleh Mahupiki dari 70 kasus pidana lingkungan hidup tahun 2002-2015, 43 \% terdakwa di vonis bebas, 40\% hanya hukuman percobaan, $2 \%$ onslag van gewisjde (lepas dari segala tuntutan hukum) dan $2 \%$ tuntutan ditolak. Hanya $13 \%$ pelaku dihukum penjara dan denda. ${ }^{8}$

\section{b. Upaya Penegakan Hukum terhadap Korporasi dalam Tindak Pidana}

\section{Lingkungan Hidup di Wilayah Provinsi Jawa Barat Dihubungkan dengan}

\section{Usaha Pemulihan Lingkungan Hidup}

Dominasi pertimbangan teknis yuridis sebagai ciri penegakan hukum yang positivistik harus digunakan sebagai pintu masuk untuk mencari kebenaran dan keadilan. Menegakan nilai-nilai kebenaran dan keadilan lingkungan merupakan tujuan utama penegakan hukum lingkungan. Bertolak dari pemikiran tersebut maka optimalisasi penegakan hukum pidana terhadap tindak pidana lingkungan oleh korporasi secara aktual dapat diterapkan sebagai berikut:

\section{Optimalisasi Penerapan Sanksi Pidana Pokok}

Penggunaan sanksi pidana pada prinsipnya diterapkan ketika sarana hukum yang lain tidak mampu menyelesaikan sengketa yang terjadi. Prinsip ini dikenal dengan "subsidiaritas" yang menempatkan hukum pidana sebagai "ultimum

\footnotetext{
${ }^{8}$ Barda Nawawi Arief, Korporasi Sebagai Subjek Hukum Pidana, Seminar Masyarakat Hukum Pidana dan Kriminologi (Mahupiki), Mei 205, hlm. 43.
} 
remidium" atau sarana hukum terakhir. Dalam penegakan hukum lingkungan di Jawa Barat pemerintah daerah berupaya mengedepankan sarana hukum administrasi untuk menjatuhkan sanksi tanpa melalui proses peradilan tetapi sebagian besar sanksi tersebut tidak dilaksanakan dengan baik oleh para pengurus korporasi. Demikian pula dengan sanksi perdata gugatan penyelesaian sengketa lingkungan secara class action melalui pengadilan tidak memuaskan masyarakat yang terdampak. Oleh karena itu perlu menerapkan beberapa strategi agar sanksi pidana dapat memberikan keadilan lingkungan (environmental justice) yaitu:

a) Sanksi Pidana Penjara Bagi Pengurus atau Organ Korporasi

Salah satu karakteristik hukum pidana adalah karena adanya ancaman pidana yang ditujukan kepada pelaku tindak pidana. Oleh karena itu ciri utama hukum pidana adalah karena adanya sanksi yaitu jenis pidana apa yang akan dijatuhkan kepada pelaku tindak pidana. Pemidanaan atau penerapan sanksi pidana (straf) sering dipandang sebagai ultimum remidium atau senjata terakhir dalam menanggulangi kejahatan. Pemberian pidana dalam arti umum merupakan bidang dari pembentuk undang-undang sesuai asas legalitas atau nullum crimen nulla poena, sine praevia lege poenale yaitu mengendakan pidana diperlukan adanya undang-undang terlebih dahulu. Jadi, yang menetapkan pidananya adalah pembentuk undang-undang untuk menentukan perbuatan mana yang dikenakan pidana. Demikian juga, permasalahan hukum dan organisatoris infrastruktur harus sudah siap, sehingga badan-badan yang mendukung stelsel sanksi pidana dapat menetapkan pidana dengan merujuk pada pelbagai infrastruktur dari penitensier itu, sehingga pemberian pidana merupakan masalah yang konkret. ${ }^{9}$

Bertolak dari uraian di atas, penerapan sanksi pidana penjara merupakan sebuah keharusan ketika terjadi tindak pidana lingkungan yang dilakukan oleh pengurus yang bertindak untuk dan atas nama korporasi. Artinya sanksi pidana dijatuhkan kepada organ atau pengurus korporasi sebagai pelaku langsung. Secara teoritis konsep ini dimungkinkan untuk diterapkan karena tindak pidana dilakukan

\footnotetext{
${ }^{9}$ Roni Wiyanto, Asas-Asas Hukum Pidana, Mandar Maju, Bandung, hlm 110
} 
oleh organ atau pengurus, tindak pidana tersebut dilakukan dalam lingkup pekerjaannya, tindak pidana dilakukan ketika pelaku bertindak untuk dan/atau atas nama korporasi atau bahkan tindak pidana yang dilakukan memberikan keuntungan atau manfaat bagi korporasi yang bersangkutan.

Penjatuhan pidana penjara dalam khazanah hukum pidana positif hanya dimungkinkan untuk diterapkan kepada manusia alamiah (naturalijk persoon) karena badan hukum (recht persoon) tidak mungkin dikenakan pidana penjara. ${ }^{10}$ Atas dasar itu sudah menjadi kewajiban hakim untuk menerapkan sanksi pidana kepada organ atau pengurus yang terbukti melakukan tindak pidana lingkungan. Argumentasi perlunya pidana penjara bagi organ atau pengurus korporasi adalah:

Pertama, korporasi sebagai badan usaha diisi oleh organ atau pengurus yang berfungsi menjalankan kegiatan usaha perusahaan untuk memperoleh keuntungan. Dalam teori identifikasi, tindak pidana yang dilakukan oleh pejabat senior (senior officer) atau yang dilakukan oleh pengambil kebijakan diidentifikasikan sebagai tindak pidana yang dilakukan oleh korporasi. Usaha untuk mendapatkan keuntungan dilaksanakan oleh pengurus korporasi dengan mengeluarkan kebijakan untuk mengeksploitasi lingkungan secara melawan hukum atau tidak sesuai dengan peraturan perundang-undangan yang berlaku atau menjadi pelaku tindak pidana secara langsung.

Kedua, keberadaan korporasi karena keinginan dari pemilik atau pemegang sahamnya dan kegiatan korporasi yang kemudian kegiatannya dilaksanakan oleh organ atau pengurusnya. Ketika korporasi memperoleh keuntungan dari tindak pidana lingkungan yang dilakukan oleh pengurusnya maka secara otomatis pula pengurus atau organ korporasi akan mendapatkan hasil kejahatan tersebut, sehingga imbalan materil (keuntungan) yang ia peroleh menjadi dasar patut dijatuhi pidana penjara bagi pengurus atau organ korporasi yang bersangkutan.

\footnotetext{
${ }^{10}$ Kristian, Kebijakan Aplikasi Sistem Pertanggungjawaban Pidana Korporasi, Sinar Grafika, Jakarta, 2018, hlm. 9.
} 
Kemungkinan menjatuhkan pidana bagi pengurus korporasi secara normatif sangat dimungkinkan ketika korporasi terbukti melakukan tindak pidana penjatuhan pidana diatur dalam Pasal 23 Perma No 13 tahun 2016 tentang Tata Cara Penanganan Tindak Pidana Korporasi, yang menyatakan bahwa:

(1) Hakim dapat menjatuhkan pidana terhadap korporasi atau pengurus, atau korporasi dan pengurus;

(2) Hakim menjatuhkan pidana sebagaimana dimaksud pada ayat (1) didasarkan pada masing-masing undang-undang yang mengatur ancaman pidana terhadap korporasi dan/ atau pengurus;

(3) Penjatuhan pidana terhadap korporasi dan/ atau pengurus sebagaimana dimaksud ayat (1) tidak menutup kemungkinan penjatuhan pidana terhadap pelaku lain yang berdasarkan ketentuan undang-undang terbukti terlibat dalam tindak pidana tersebut.

Penjatuhan pidana penjara bagi pengurus korporasi dianalisis dari teori pemidanaan menjadi persoalan yang urgen untuk diterapkan karena pidana penjara memiliki fungsi pencegahan umum (general prevention) dan pencegahan khusus (special prevention). ${ }^{11}$ Fungsi pencegahan umum ditujukan agar pengurus korporasi secara umum yang berada di wilayah Jawa Barat dalam mengeksploitasi lingkungan tidak melanggar peraturan perundang-undangan di bidang lingkungan hidup yang berlaku, sedangkan pencegahan khusus bertujuan agar setiap pengurus korporasi yang berpotensi melanggar aturan hukum pidana dapat terhindar dari tindak pidana lingkungan yang berdampak pada penjatuhan sanksi pidana.

Selama ini realitas pencemaran dan perusakan lingkungan di seluruh wilayah Jawa Barat lebih banyak di dominasi oleh korporasi di mana peran pengurus korporasi sangat vital baik sebagai pengambil kebijakan maupun sebagai pelaku langsung. Tidak hanya sebagai pengambil kebijakan dan pelaku langsung, pengurus dalam beberapa kasus yang ditangani Satgas penegakan hukum lingkungan terpadu (one roof enforcement system) Jawa Barat juga menjadi inisiator terjadinya upaya-

${ }^{11}$ Dey Ravena dan Kristian, Kebijakan Kriminal, Kencana, 2017, hlm. 158. 
upaya perusakan lingkungan, karena dalam menjalankan kegiatan usaha pengurus kadangkala dibenturkan dengan biaya (cost) produksi yang tinggi sehingga mereka harus berfikir untuk menekan biaya produksi seminimal mungkin.

b) Penerapan Pidana Denda bagi Korporasi

Peranan akta otentik dalam pemberian lisensi sangat penting, karena mempunyai daya pembuktian kepada pihak ketiga, yang tidak dipunyai oleh akta di bawah tangan, sedangkan akta di bawah tangan mempunyai kelemahan yang sangat nyata yaitu orang yang tanda tangannya tertera dalam akta di bawah tangan dapat mengingkari keaslian tanda tangan itu. Jadi untuk melindungi hak ekonomi para pihak sebaiknya perjanjian lisensi dituangkan dalam akta otentik. Pembuatan akta otentik sangat berbeda dengan akta di bawah tangan. ${ }^{12}$

Bentuk/jenis sanksi pidana yang sesuai dengan prinsip analisis efisiensi atas hukum pidana dalam menanggulangi tindak pidana lingkungan adalah pidana denda (fine) atau sejenisnya. Secara ekonomis denda adalah pidana yang paling efisien karena dalam pelaksanaannya tidak memerlukan biaya apapun, hanya berkaitan dengan kewajiban pelaku untuk membayar sejumlah uang kepada negara. Negara sendiri tidak perlu mengeluarkan biaya apapun ketika menjatuhkan sanksi pidana denda.

Kemungkinan menetapkan pidana penjara pengganti didasarkan pada pendapat Barda Nawawi Arief bahwa strategi kebijakan pemidanaan dalam kejahatan-kejahatan yang berdimensi baru harus memperhatikan hakekat permasalahan. Bila hakekat permasalahannya lebih dekat dengan masalah-masalah di bidang hukum perekonomian maka lebih diutamakan penggunaan pidana denda atau semacamnya. Penetapan sanksi pidana seharusnya dilakukan melalui pendekatan rasional. Bila berdasar pada konsep rasional ini, maka kebijakan penetapan sanksi pidana tidak terlepas dari penetapan tujuan yang ingin dicapai oleh kebijakan kriminal secara keseluruhan, yakni perlindungan masyarakat. ${ }^{13}$

\footnotetext{
12 Moeljatno, Kitab Undang-Undang Hukum Pidana, Bumi Aksara, Jakarta, 1994, hlm. 18.

${ }^{13}$ Barda Nawawi Arief, Pembaruan Penegakan Hukum dengan Nilai-nilai Moral Religius, Makalah disampaikan pada Seminar Nasional Menembus Kebuntuan Legal Formal Menuju Pembangunan Hukum dengan Pendekatan Hukum Progresif, FH Undip 19 Desember 2009. Hlm 13.
} 
Tujuan penjatuhan sanksi pidana apabila dikaji dari segi filosofi cita penegakan hukum menurut Gustav Redbruch ada 3 (tiga) ide dasar hukum yang mesti dicapai dalam sebuah penegakan hukum yaitu keadilan, kemanfaatan dan kepastian hukum. Ketiga elemen ini banyak jurist menyebut sebagai tujuan hukum atau ide dasar dalam berhukum, Redbruch menyatakan adanya kesulitan dalam mewujudkan ketiga tujuan hukum tersebut secara bersamaan. Namun Redbruch mengajarkan bahwa penegak hukum harus menggunakan asas prioritas di mana prioritas utama jatuh pada keadilan, baru kemanfaatan dan terakhir kepastian hukum. ${ }^{14}$ Mardjono Reksodiputro mengemukakan bahwa tujuan penegakan hukum tidak hanya menggunakan asas prioritas, namun juga perlu prioritaskasuistis. Penulis sendiri lebih realistis untuk menerapkan asas prioritas yang kasuistis, artinya ketiga tujuan hukum itu harus diprioritaskan sesuai dengan kasus yang dihadapi. Dengan kata lain harus dilihat secara case by case. ${ }^{15}$

Penegak hukum harus mengutamakan asas keadilan, kemanfaatan dan barulah kepastian hukum, mengingat tindak pidana lingkungan adalah kejahatan yang dilakukan bukan karena kebutuhan (crime not by need) melainkan karena kepentingan bisnis (crime by business interests). Oleh karena itu, perlu penyesuaian mengenai sanksi pidana yang akan diterapkan. Hakim perlu mempertimbangkan aspek keadilan dan kemanfaatan dari pembayaran pidana denda, akan lebih adil dan bermanfaat bagi masyarakat dan lingkungan jika putusan yang dijatuhkan adalah pidana denda.

Menurut pandangan penulis pidana denda sangat sesuai diterapkan kepada korporasi sebagai lembaga (badan usaha) karena korporasi melakukan tindak pidana lingkungan untuk memperoleh keuntungan dari kegiatan bisnisnya. Meski demikian penulis berpandangan bahwa pengelolaan dana hasil pidana denda yang masuk ke Penghasilan Negara Bukan Pajak (PNBP) tidak cukup tepat karena dana

\footnotetext{
${ }^{14}$ Ahmad Miru dan Sutarman Yodo, Hukum Perlindungan Konsumen, PT Raja Grafindo Persada, Jakarta, 2015, hlm 26

${ }^{15}$ Ilham Hermawan, Hermeneutika Hukum, Refika Aditama, Bandung, 2018, Hlm 98.
} 
tersebut digunakan untuk membiayai program-program pemerintah secara umum, dalam artian tidak berdampak langsung terhadap perbaikan lingkungan.

Sebagai usaha memperbaharui pola pengelolaan dana hasil pembayaran pidana denda sebaiknya di masa mendatang dikelola oleh Kementerian Lingkungan Hidup dan Kehutanan (KLHK) di mana dalam pengelolaannya dilaksanakan secara transparan, akuntabel dan bertanggungjawab. Pengelolaan dana hasil pembayaran pidana denda dikelola berdasarkan prinsip kehati-hatian dan digunakan untuk upaya pemulihan lingkungan. Sejumlah uang yang dibayarkan korporasi harus digunakan untuk kepentingan pemulihan lingkungan sehingga lebih memberikan keadilan bagi lingkungan yang rusak yang membutuhkan dibandingkan dengan memberikan kesempatan terpidana untuk mengganti dengan pidana penjara.

Implementasi pembayaran pidana denda selain harus memperhatikan keadilan lingkungan (environmental justice) juga perlu memperhatikan prinsip ekonomi yaitu efisiensi (efficiency) keseimbangan (equilibrium), dan maksimalisasi (maximization). Dengan demikian implementasi pembayaran pidana denda akan mampu mencapai tujuan pemulihan lingkungan.

Putusan hakim berupa pidana denda bagi korporasi diharapkan menciptakan efisiensi (efficiency) yang melahirkan keadilan dan kemanfaatan karena negara tidak perlu mengeluarkan ongkos yang besar untuk eksekusi pidana denda. Pidana denda juga diharapkan memberikan keseimbangan (eqilibrium) lingkungan setelah sebelumnya rusak dan tercemar.

Pidana denda yang diatur dalam Undang-Undang No 32 Tahun 2009 Tentang Perlindungan dan Pengelolaan Lingkungan Hidup dilihat dari segi jumlahnya memang tidak begitu besar karena nilai minimumnya telah ditentukan secara limitatif sebesar Rp 1.000.000.000,- (satu milyar) dan maksimum $\mathrm{Rp}$ 15.000.000.000,- (lima belas milyar) dibandingkan dengan biaya yang dibutuhkan untuk melakukan kegiatan pemulihan lingkungan tetapi dikaji dari segi manfaat dana yang terkumpul dari pembayaran pidana denda akan cukup bermanfaat untuk upaya pemulihan lingkungan. 
Model pengelolaan dana hasil pembayaran pidana denda oleh KLHK menjadi salah satu upaya solutif agar pemanfaatan dana tersebut lebih terfokus, terarah dan sesuai peruntukannya. Pemanfaatan dana ini melibatkan instansi yang berwenang di bidang perlindungan dan pengelolaan lingkungan hidup di tingkat daerah yang dalam hal ini diwakili oleh Dinas Lingkungan Hidup Provinsi Jawa Barat sehingga diharapkan lingkungan yang mengalami kerusakan karena kegiatan usaha korporasi dalam diperbaiki kembali sehingga penggunaan dana hasil pidana denda betul-betul dialokasikan untuk kegiatan rehabilitasi lingkungan.

Implementasi pelaksanaan pidana denda di lapangan tetap dilaksanakan oleh jaksa sebagai eksekutor putusan pengadilan berkoordinasi dan bekerjasama dengan DLH Jabar untuk bersama-sama melakukan pengawasan penggunaan dana hasil pembayaran pidana denda untuk kegiatan pemulihan lingkungan. Eksekusi pidana denda tanpa adanya kerjasama jaksa dengan DLH akan mengalami kesulitan, maka konsep Satgas penggeman hukum lingkungan terpadu menjadi suatu kebutuhan yang nyata dalam usaha menggunakan pidana denda untuk kepentingan pemulihan lingkungan.

\section{Optimalisasi Pidana Tambahan Berupa Perbaikan Akibat Tindak} Pidana

Pidana tambahan dalam khazanah hukum pidana Indonesia merupakan jenis sanksi yang bersifat fakultatif dan komplementaris (pelengkap) dari pidana pokok yang dijatuhkan kepada pelaku tindak pidana. Setiap peraturan hukum pidana khusus biasanya dilengkapi dengan sanksi pidana tambahan yang fungsinya menambah pidana pokok yang dijatuhkan hakim di pengadilan.

Pidana tambahan adalah pidana yang bersifat menambah pidana pokok yang dijatuhkan sehingga tidak dapat berdiri sendiri. Pidana tambahan ini bersifat fakultatif artinya dapat dijatuhkan tetapi tidaklah harus. Menurut Hermin Hediati bahwa ketentuan pidana tambahan ini berbeda dengan ketentuan bagi penjatuhan pidana pokok, yaitu: 
a. Pidana tambahan hanya dapat dijatuhkan disamping pidana pokok, artinya pidana tambahan tidak boleh dijatuhkan sebagai pidana satusatunya.

b. Pidana tambahan hanya dapat dijatuhkan apabila di dalam rumusan suatu perbuatan pidana dinyatakan dengan tegas sebagai ancaman.

c. Pidana tambahan bersifat fakultatif karena dalam penjatuhannya diserahkan kepada hakim untuk.

Meskipun pidana tambahan fungsinya hanya menambah tetapi dalam pidana ini memiliki daya jera bagi pelaku tindak pidana, bahkan kadangkala daya jera pidana tambahan jauh lebih efektif dari pidana pokoknya. Dalam kasus-kasus tertentu pidana tambahan memiliki fungsi memulihkan kerugian yang diakibatkan tindak pidana. Sebagai contoh dalam Undang-Undang pemberantasan tindak pidana korupsi merumuskan pidana tambahan berupa pembayaran uang pengganti yang bertujuan untuk mengembalikan kerugian negara.

Usaha untuk pemulihan lingkungan membutuhkan keberanian hakim untuk memberantas korporasi-korporasi yang selama ini terlepas dari kewajiban perbaikan lingkungan. Upaya perbaikan lingkungan hukum pidana telah mengaturnya dalam ketentuan pidana tambahan yang sifatnya sebagai pelengkap tetapi memiliki efek manfaat yang sangat besar untuk mencapai keadilan lingkungan.

Aturan pidana tambahan dalam Undang-Undang No 32 Tahun 2009 tentang Perlindungan dan Pengelolaan Lingkungan Hidup diatur dalam Pasal 119 yang menyatakan bahwa:

Usaha pemulihan lingkungan melalui instrumen hukum pidana pada dasarnya bisa menerapkan ketentuan pidana tambahan sebagaimana diatur dalam Pasal 119 huruf c, aturan ini sangat baik bila penegak hukum berani mengancamkan pidana perbaikan akibat tindak pidana. Bentuk perbaikan akibat tindak pidana dilakukan dengan beberapa usaha yaitu:

a. Remediasi upaya ini bertujuan memberikan pemulihan pencemaran lingkungan hidup untuk memperbaiki mutu lingkungan hidup. 
b. Rehabilitasi adalah upaya pemulihan untuk mengembalikan nilai, fungsi, dan manfaat lingkungan hidup termasuk upaya pencegahan kerusakan lahan, memberikan perlindungan, dan memperbaiki ekosistem.

c. Restorasi adalah upaya pemulihan untuk menjadikan lingkungan hidup atau bagian- bagiannya berfungsi kembali sebagaimana semula

Fungsionalisasi sanksi pidana tambahan sebagaimana dimaksud Pasal 119 huruf c memiliki nilai (ide dasar) untuk menciptakan keadilan terhadap lingkungan yang menjadi objek kegiatan usaha, tetapi dalam praktek penegakan hukum lingkungan terpadu jenis sanksi pidana ini hampir tidak pernah diterapkan oleh penegak hukum sanksi pidana hanya sampai pada pengurus saja, sehingga meskipun sanksi pidana dijatuhkan tetapi lingkungan tetap rusak dan tercemar.

Pemikiran penulis berkaitan dengan penegakan hukum pidana terhadap korporasi untuk memulihkan lingkungan, secara skematis dapat digambarkan di bawah ini:

\section{Gambar}


Konsep Penegakan Hukum Pidana Terhadap Korporasi untuk Pemulihan

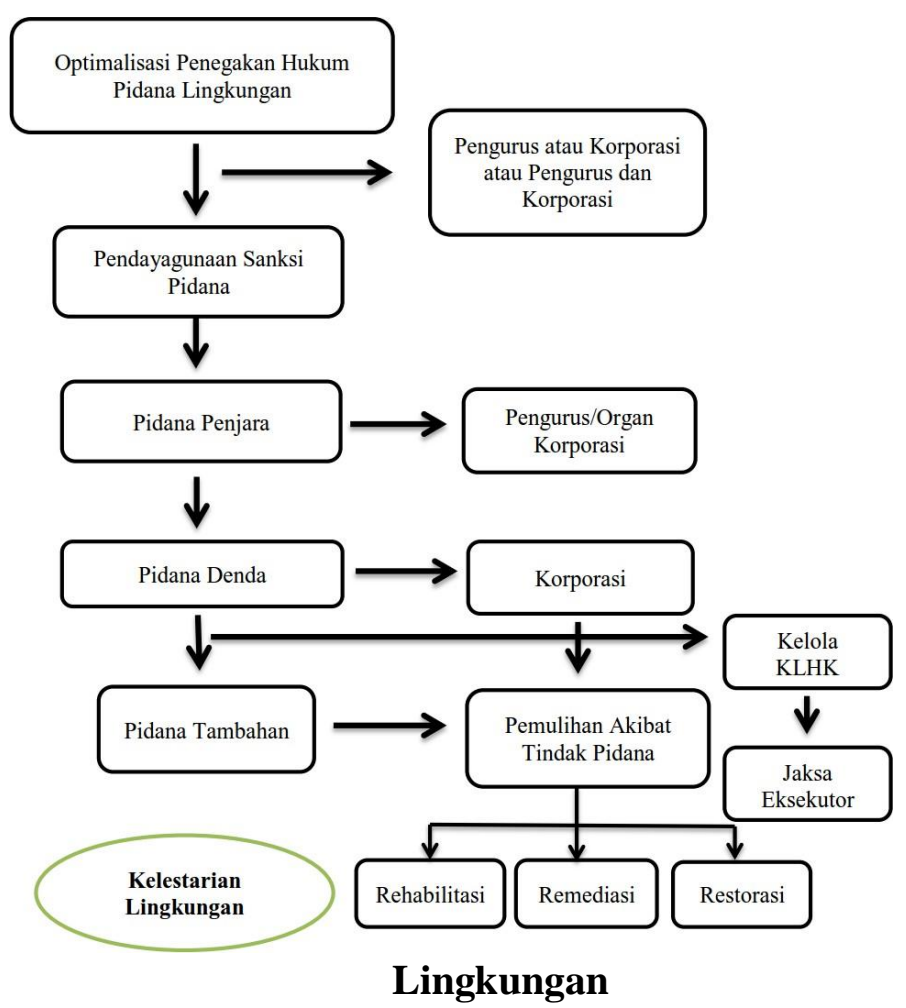

Berdasarkan pemikiran model penegakan hukum sebagaimana tercantum dalam gambar ide dasar untuk mengembalikan kelestarian ekosistem lingkungan yang rusak dan tercemar dapat dipulihkan dengan mendayagunakan sarana hukum pidana.

\section{PENUTUP}

Implementasi penegakan hukum pidana terhadap tindak pidana korporasi di wilayah Provinsi dilaksanakan dengan membentuk Satgas penegakan hukum lingkungan terpadu (one roof enforcement system) serta menggunakan Perma No 13 Tahun 2016 tentang Tata Cara Mekanisme Penanganan Tindak Pidana Korporasi sebagai pedoman tetapi secara faktual hanya sedikit korporasi yang dikenakan sanksi pidana karena Satgas kesulitan untuk membuktikan unsur delik yang dalam penyajian data dan faktanya seringkali bersifat ilmiah (scientific proof) dan terbentur beberapa persoalan mendasar yang menjadi kendala yaitu (a) ketidakkelasan kriteria rumusan 
delik dalam undang-undang (b) keterbatasan sumber daya manusia (personil) yang kompeten di bidang lingkungan (c) sarana dan prasarana (d) masalah anggaran. Akibatnya penindakan terhadap korporasi dengan menggunakan instrumen hukum pidana tidak memberikan efek jera dan belum menghasilkan pemulihan terhadap lingkungan yang rusak dan tercemar.Perjanjian lisensi yang dibuat di bawah tangan oleh pencipta lagu dengan produser rekaman (label) memiliki kekuatan hukum yang mengikat seperti undang-undang bagi para pihak yang membuatnya sepanjang memenuhi syarat sahnya perjanjian yang ditentukan dalam Pasal 1320 KUHPerdata dan asas pact sunt servanda, tetapi apabila perjanjian lisensi atas lagu di bawah tangan disangkal oleh salah satu pihak, maka pihak yang mengajukan tuntutan pembayaran royalti (hak ekonomi) atas pemberian lisensi harus membuktikan kebenaran isi perjanjian lisensi tersebut melalui alat bukti lain.

Upaya penegakan hukum pidana terhadap tindak pidana korporasi lingkungan di Provinsi Jawa Barat memerlukan konsep penegakan hukum yang berorientasi pada pemulihan dan keadilan lingkungan (environmental justice) dengan menuntut pertanggungjawaban pidana terhadap korporasi atau pengurus, atau korporasi dan pengurus sebagai pembuat tindak pidana berupa (a) menjatuhkan pidana penjara kepada pengurus korporasi sebagai pengambil kebijakan maupun sebagai pelaku langsung (b) menerapkan sanksi pidana denda (criminal fines) yang dikelola oleh KLHK dan digunakan khusus untuk kepentingan pemulihan lingkungan (c) menjatuhkan sanksi pidana tambahan yaitu perbaikan akibat tindak pidana berupa: 1) pemulihan (remediasi); 2) pemulihan nilai, fungsi, dan manfaat lingkungan (rehabilitasi); 3) pemulihan untuk menjadikan lingkungan hidup atau bagian- bagiannya berfungsi kembali seperti semula (restorasi).

Dengan demikian tindak pidana korporasi sebagai kejahatan bisnis "economic crime" atau "abuses of economic power", dalam penanganannya memiliki kesulitan tersendiri. Oleh karena itu dalam penegakan hukum tindak pidana korporasi di bidang lingkungan hidup disarankan untuk:

a. Membuat peraturan pelaksana Undang-Undang 32 Tahun 2009 tentang Perlindungan dan Pengelolaan Lingkungan Hidup untuk delik-delik 
tertentu yang membutuhkan penjelasan kriteria tertentu.

b. Meningkatkan personil penegak hukum (Kepolisian, Kejaksaan, PPNS Jabar dan Hakim) dari segi kualitas maupun kuantitas dengan mengadakan pelatihan sertifikasi khusus bagi penyidik, penuntut umum dan hakim di bidang tindak pidana lingkungan agar mampu menuntaskan kasus-kasus lingkungan yang melibatkan korporasi dan membawanya ke pengadilan.

c. Meningkatkan anggaran DLH Jabar sebagai coordinator institution dalam one roof enforcement system sehingga bisa memenuhi kebutuhan selama pro justitita termasuk membangun laboratorium tersendiri.

Usaha menanggulangi tindak pidana lingkungan yang melibatkan korporasi dengan hukum pidana sebaiknya diarahkan pada optimalisasi penjatuhan pokok berupa:

a. Pidana penjara bagi pengurus/organ korporasi sebagai subjek hukum manusia alamiah (naturelijk person) untuk memberikan efek jera baik secara individu (special prevention) maupun secara sosial (general prevention), dan mendayagunakan sanksi pidana denda bagi korporasi sebagai subjek hukum badan usaha (recht person) yang dapat dimintai pertanggungjawaban pidana.

b. Pidana tambahan bagi korporasi untuk melakukan perbaikan akibat tindak pidana lingkungan melalui usaha rehabilitasi, remediasi dan restorasi sehingga lingkungan yang mengalami kerusakan atau pencemaran dapat dipulihkan kembali. 


\section{DAFTAR ISI}

\section{A. Buku}

Ahmad Miru dan Sutarman Yodo, Hukum Perlindungan Konsumen, PT Raja Grafindo Persada, Jakarta, 2015.

Dey Ravena dan Kristian, Kebijakan Kriminal, Kencana, 2017.

Hartiwiningih, Hukum Lingkungan dalam Perspektif Kebijakan Hukum Pidana, UNS Surakarta, 2008.

Ilham Hermawan, Hermeneutika Hukum, Refika Aditama, Bandung, 2018.

Mas Achmad Santosa. Kata Pengantar dalam Sembiring. Raynaldo., (et.all). Anotasi Undang Undang Nomor 32 Tahun 2009 Tentang Perlindungan Dan Pengelolaan Lingkungan Hidup, Edisi Pertama, (Jakarta: Indonesian Center for Environmental Law (ICEL), 2014).

Moeljatno, Kitab Undang-Undang Hukum Pidana, Bumi Aksara, Jakarta, 1994. Kristian, Kebijakan Aplikasi Sistem Pertanggungjawaban Pidana Korporasi, Sinar Grafika, Jakarta, 2018.

Roni Wiyanto, Asas-Asas Hukum Pidana, Mandar Maju, Bandung, 2012.

\section{B. Jurnal/Makalah}

Barda Nawawi Arief, Pembaruan Penegakan Hukum dengan Nilai-nilai Moral Religius, Makalah disampaikan pada Seminar Nasional Menembus Kebuntuan Legal Formal Menuju Pembangunan Hukum dengan Pendekatan Hukum Progresif, FH Undip 19 Desember 2009.

Barda Nawawi Arief, Korporasi Sebagai Subjek Hukum Pidana, Seminar Masyarakat Hukum Pidana dan Kriminologi (Mahupiki), Mei 2015.

I.S. Susanto, Tinjauan Kriminologis tentang Kejahatan Ekonomi, Makalah pada Penataran Hukum Pidana dan Kriminologi, UNDIP, Semarang 23-30 November 1998.

Saifuddin, Tindak Pidana Lingkungan Korporasi, Makalah disampaikan pada Simposium Hukum Pidana, Universitas Lambung Mangkurat, Banjarmasin, 2015.

\section{Peraturan Perundang-undangan}

Undang-Undang Dasar 1945

Undang-Undang No 32 Tahun 2009 Tentang Perlindungan dan Pengelolaan Lingkungan Hidup 